\title{
Egypt Demographic Trends and Socio-Economic Implications
}

\section{Marwan Naser}

Senior Research Fellow, Department of International Development, The London School of Economics and Political Science LSE, Houghton Street, London, United Kingdom.

*Correspondence author: Marwan Naser, Senior Research Fellow, Department of International Development, The London School of Economics and Political Science LSE, Houghton Street, London, United Kingdom; Tel: +44 7703 447233; E-mail: m.naser@lse.ac.uk

Rec Date: Jun 30 2014; Acc Date: Jul 15 2014; Pub Date: Jul 222014

Copyright: (C) 2014 Naser M. This is an open-access article distributed under the terms of the Creative Commons Attribution License, which permits unrestricted use, distribution, and reproduction in any medium, provided the original author and source are credited.

\section{Abstract}

The aim of this article is to examine the implications of demographic change in Egypt. This paper provides new grounds for research and applications in designing, developing, implementing and institutionalizing decision support and their use in socio-economic development. This work goes beyond both a theoretical expectation and empirical evidence that rapid population growth is one of the crucial problems that have hindered development efforts in the region; it carries serious implications for employment, access to services and the cost of subsidies. These could spell serious political consequences in what is already a politically unstable state. Population data for Egypt are extremely sensitive and need to be treated cautiously. Nonetheless, it is clear that Egypt since the 1970s has experienced a dramatic rise in population compared to other parts of the developing world. Despite the progress of economic reforms and structural adjustments program applied during the past years, Egypt is still suffering in the beginning of the twenty first century- from a slowdown in the economic activity, a shortage in foreign exchange earnings, structural imbalances in the labor market, a high rate of unemployment, and a growing government deficit. Rapid population growth in a country known for its scarcity of inhabitable land and fresh water could put an extraordinary strain on the environment and could turn it to an untenable population density.
\end{abstract}

Keywords: Population; Economic growth; Demographic transition; Decision support

\section{Context}

Egypt is struggling to contain a population explosion that has surged in the past few years. Despite the successes achieved in lowering the population growth rate (Figure 1) from 2.75 in 1986 to 1.92 in 2012, the population of Egypt went from 51,911,000 in 1990 to $63,860,000$ in 2000 [1], 78,728,00 in 2010 and reached 86,132,143 in 2014 [2]. The Total Fertility Rate (TFR) [3] declined from 5.03 in 1980 to 3.3 in 2012 but remains far to the replacement level of 2.1 children per woman by 2017 .

The UN population division has published a new projection under which the population will reach $123,452,000$ in 2050 . Egyptian policy leaders assured that the annual increase in population will be one of the main obstacles to achieving the economic growth and development.

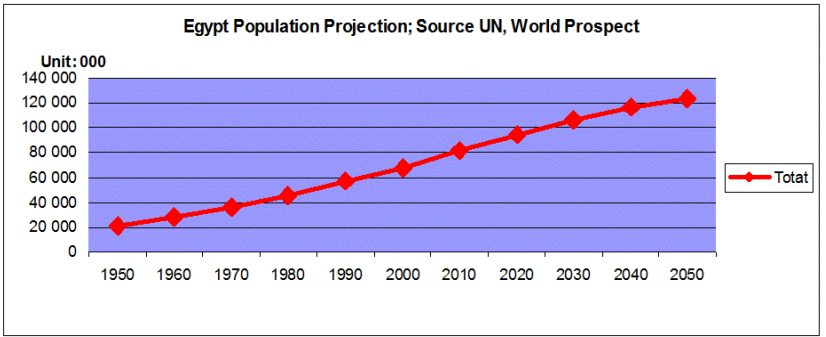

Figure 1: Egypt Population Projection

\section{What is Next}

Even though Egypt has put huge efforts in maintaining and sustaining the achieved rates and has ambitious aspirations to enhance their achievements in all infrastructure, production and service sectors. The rising population [4] will drain Egypt's natural resources; the country already faces severe water, energy and wheat shortages and lacks foreign currency reserves needed to fund the import of extra supplies. The population increase challenges all efforts to provide more and better-quality services, create job opportunities, curb unemployment, improved standard of living and could even pose a threat to Egypt's social stability and national security. However, Demographic advantage of young population is in that it provides for the increase of labour force, but not automatically the economic growth [5]. Economic progress depends on the capability of a country to turn the higher inflow of young labour force into employment growth. This may be reached by special social and economic reforms such as the reform of the educational system and the labour market.

\section{Analysis}

Egypt is the most populous country in the Arab world and the second most populous on the African continent, the scarcity of arable land and water resources has forced people to live in the narrow strip of fertile land along the Nile River [6].

The median age of the population was 24.6 in 2012 compared to 22.9 in 2005 , life expectancy at birth increased from 68.6 for male and 71,1 for female in 2011 to 69 for male and 71.7 for female in 2012 .

The working age population 15 to 65 years old is expected to rise from 63.4 in 2010 to 63.9 in 2015. 
Page 2 of 4

The proportion 0-14 years old is expected to drop from 31.5 in 2010 to 30.2 in 2015 whereas the over 65 years are expected to grow from 5.0 in 2010 to 5.9 in 2015, this shift represents a demographic window of opportunity with the total population (Figure 2) being of working age [7], The challenge is to provide jobs to the growing labour force and medical and other support programs to the elderly.

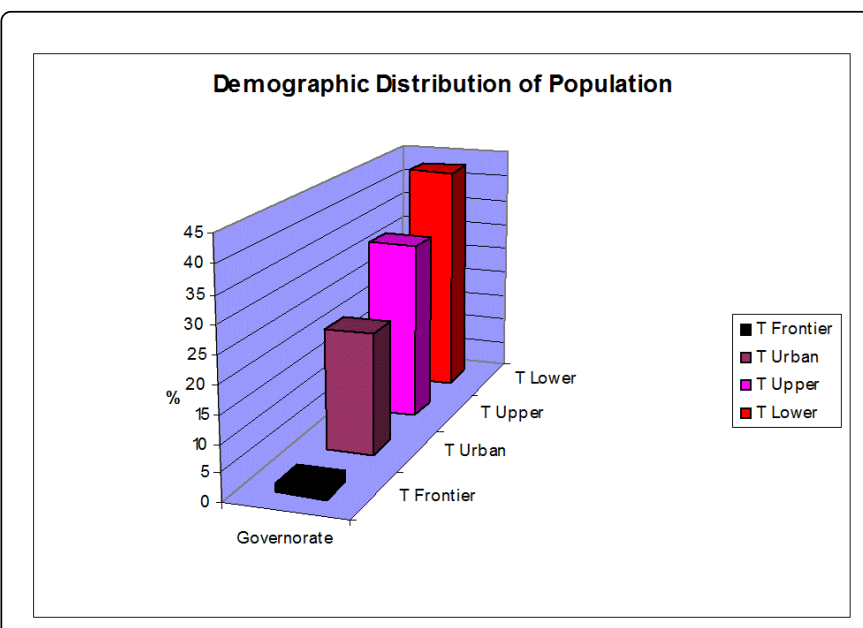

Figure 2: Demographic Distribution of Population

Population in urban areas is expected to grow from 43.3 in 2010 to 60.3 in 2050 and to drop in rural areas from 56.7 to 39.7 for the same period.

The Population is condensed in less than $10 \%$ of the total area of Egypt, which is one million square kilometers and is concentrated in a narrow band between the Eastern and Western deserts. 43\% of total population lives in the fertile Nile Delta (Lower Egypt), 32.9 in the Nile Valley (Upper Egypt) and 22.3 in urban provinces.

Greater Cairo is one of the world's most densely populated urban areas. Consisting of Cairo governorate, Giza city, Kalioubia, $6^{\text {th }}$ October City and Helwan with a total population of 19,439,541 as per the 2006 census [8]. In March 2014 the three provinces of Cairo governorate, Kalioubiya, Giza city reached a total of 21,561,399 (25, $03 \%$ ) of the total population, followed by Alexandria with a population of $4,711,812$.

\section{Demographic Trend}

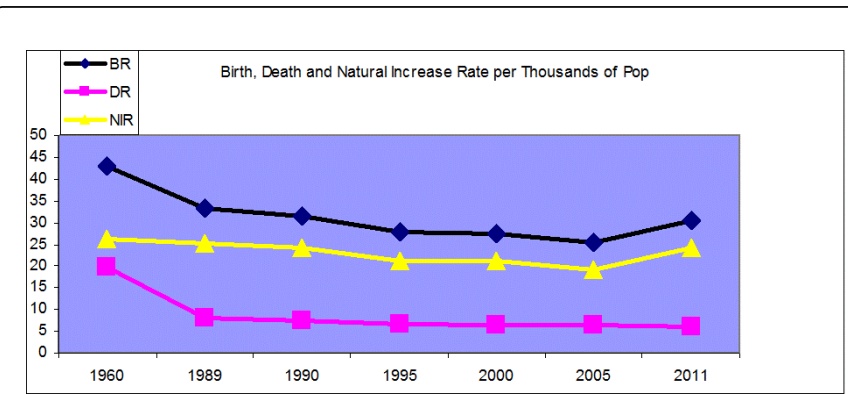

Figure 3: Birth, Death and Natural Increase Rate per Thousands of Pop
Egypt's demography has followed a classic transition [9] from high fertility and mortality to lower fertility and mortality with consequent declining in TFR (Figure 3) in the last century.

The contraceptive prevalence rate has increased from $24.2 \%$ in 1980 to $60.3 \%$ in 2010 . It is clear that the increase in family planning use have been a significant factor in this decline, but the administrative chaos that followed the 2011 uprising led to a drop off in contraception [10]; related awareness programmes and there was a mess in terms of public health. However, Egypt continues to face urgent demographic challenges now and in the future and remain many years away from achieving population stabilization $[11,12]$.

\section{Implications of the Demographic Growth on Social Economy}

The challenge of demographic change and its widespread economic and social implications have received considerable attention in recent years. Egypt will be increasingly confronted with the complex of population change in the coming years [13]. The nature and scale of the demographic developments will however differ substantially across Egypt governorates [14].

Regardless of the level of economic development or national income, Egypt governments are increasingly challenged to provide the basic needs for a growing numbers of citizens adequate housing, sanitation, health care, education, and jobs and to combat poverty, narrow the gap between the rich and the poor, and generally improve the standard of living, in addition to the region's scarce water resources.

Mubarak undertook ambitious domestic economic reform program to reduce the size of the public sector and expand the role of the private sector. He developed the utilities, telecommunications, educational, and industrial infrastructures [15]. But most of these achievements were swamped by deficient administration for public services, thousands of graduates with no discernible future, skewed distribution of wealth and corruption.

Demographics also complicated the picture, the most important negative influences are: unemployment and very slow opening of new jobs, as a consequence of too high and abrupt increase of labour force (Figure 4); increase of public expenditure, as a result of general population growth, and the pressure on already limited resources (natural resources - food and water, as well as infrastructure and health care) which cannot meet the requirements of the growing population [16].

Instead of necessary adjustment programs, the government covertly cut subsidies and gradually retired from public services. This policy negatively affected dependent social groups on the state's welfare services. The quality of public services worsened and the quality of the education system decreased.

The crushing socio-economic conditions, widespread corruption, and gap between the rich and the poor fuelled the anger that many Egyptians felt towards the Mubarak's regime. Population control, which was relatively successful during the 80 s and 90 s, started to fall off the agenda during the last years of Mubarak's regime and was largely ignored in the chaos that followed his removal in 2011.

The negligence became official policy in 2012 when Mr Mohammed Morsi (a religious conservative) won the election and his administration publicly declared that the family planning was no 
Page 3 of 4

longer a priority and the population control was not a government concern. During Morsi's regime the National Population Council [17] was not working and population control was seen as an attempt to disrupt traditional family life, which did not play well with his socially conservative Muslim Brotherhood. The economy remains far from recovery. In May 2013 the unemployment is at 3,6 million $(13,2 \%)$ an increase of 1,2 million since 2010 (Figure 5); the total work force reached 27,3 million an increase of 1,09 million in 2010. Egypt's economy needs to grow between 5 to $7 \%$ to be able to create 800,000 new jobs a year, local currency is ailing; tax revenues shrank, budget deficit surged, and growth is subdued until further notice [18].

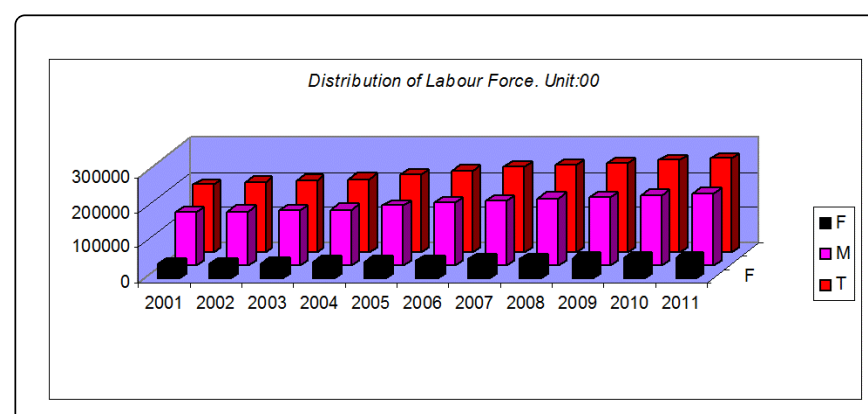

Figure 4: Distribution of Labour Force

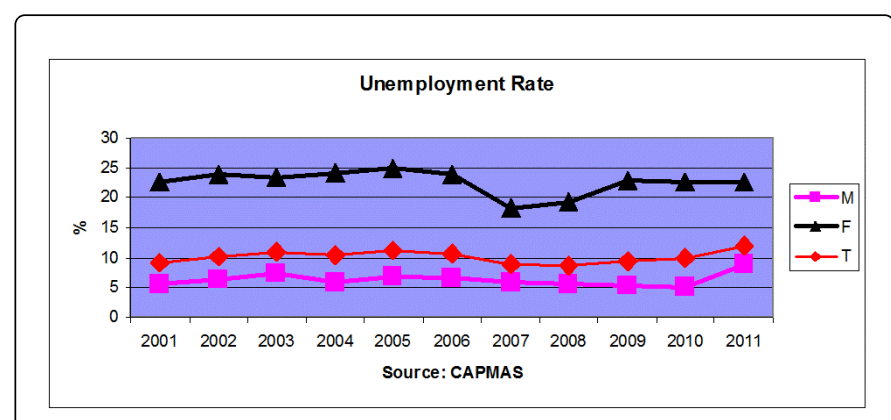

Figure 5: Unemployment Rate

Socio-economic policies and measures of Morsi's regime do not differ from those of Mubarak's regime with their bias towards the interests of the business class; failure to address social injustices; and dependency on western capital and International Financial Institutions' prescriptions. Egypt has been seeking a full $\$ 4.8$ billion from the IMF, but securing the aid would involve a commitment to austerity measures which cannot be implemented without facing backlash. It is clear that the current labour market conditions in Egypt raise doubts as to whether these economies will be able to absorb the significant expansion of the labour force.

Egypt with a large proportion of young adults in the population who are not politically and economically engaged in terms of GDP, education, employment [19], income distribution, quality of life and freedom, may be a source of tension and unrest. Egypt therefore is much less likely to attain a stable liberal democracy than the ones with a more mature age structure.

\section{Window of Opportunities}

To address the socio-economic challenges facing Egypt, policy makers should promote the role of private sector, increase foreign investment, consider diversifying its productive structure diminishing its vulnerability to external shocks; radical changes and the modernization of the educational system to meet the demands of labour market and promote economic growth, create more and better quality jobs to satisfy the increasing educated youth and reduce regional and income disparities; reforming its social welfare system [20], extending the coverage of public social services. Without these reforms the deterioration of the socio-economic conditions is expected to continue.

Family planning (FP) policy to focus on identifying the factors that are positively related to change in the use of contraception, the rate of increase from one region to another and the contribution to the fertility transition in Egypt [21], health education for women particularly in rural areas and recruiting new FP users will have a significant impact.

The government could include in its policies given Areas of desert and agricultural lands to be cultivated by the youth this way the inhabited areas will be expanded to readjust the unbalanced distribution on the land.

Long-term stable development in the next decade will depend on how management of natural and human resources will be established in the following period. Policy makers must be conscious of the severe limitations in water availability. Job creation should not be on heavily water-consuming industries.

Currently the government appears to be with little control and no sense of direction, this political gridlock and fiscal problems are preventing the government from implementing and putting in place the necessary policies.

\section{References}

1. Blackburn RD, Cunkelman JA, Zlidar VM (2000) Oral contraceptives-An update. Population Report, Series A. No 9. Baltimore, Maryland, USA.

2. Central Agency of Public Mobilization and Statistics 2006- 2014.

3. Robison WC, El-Zanaty FH (1995) The impact of Policy and Program on Fertility in Egypt: The Egyptian Family Planning Success Story.

4. (2006) Policy Project in Egypt and The Future Group International in collaboration with Research Triangle Institute, and Center for Development and Population Activities (CEDPA).

5. Dinic J (1999) Ekonomska geografija.

6. Rached E, Craissati D (2000) Research for Development In The Middle East And North Africa. IDRC, Canada.

7. United Nations Department of Economic and Social Affairs/Population Division (2011) World Population Prospects: The 2010, Volume II: Demographic Profiles

8. Carl Haub (2006) World Population Data Sheet. Population Reference Bureau, Washington, DC.

9. Laipson E (2002) The Middle East's Demographic Transition: What Does It Mean?. J Int Aff 56: 175.

10. Chao DNW (2004) Family Planning in Egypt is a sound Financial Investment. Washington, DC.

11. Cordesman AH, Burke AA (2001) Economic, Demographic, and Security Trends in the Middle East, Center for Strategic and International Studies, Washington, D.C. 
12. Roudi F (2001) Population Trends and Challenges in the Middle East and North Africa. United Nations Population Division, World Urbanization Prospects.

13. Yousef TM (2005) Macroeconomic Aspects of the New Demography in the Middle East and North Africa. Department of Economics School of Foreign Service Georgetown University, Washington, D.C.

14. Robison WC, El-Zanaty FH (2005) The Demographic revolution in Modern Egypt. Lexington Books.

15. Timmins KJ (2000) Annual Report UNIDO 2000, United Nations Industrial Development Organization.

16. Yousef T (1999) Demographic Transitions and Economic Performance in MENA. Economic research forum 5: 4.
17. National Population Council 1981-2014.

18. Moreland RS (1996) Investing in Egypt's Future.

19. The World Bank (2004) Unlocking the Employment Potential in the Middle East and North Africa: Toward a New Social Contract. Washington, D.C.

20. Ruble B (2003) Youth in the Arab World: Demography, Employment and Conflict", Youth Explosion in Developing World Cities: Approaches to Reducing Poverty and Conflict in an Urban Age, Woodrow Wilson Center.

21. Abdel-Azeem F, Farid SM, Khalifa AM (1993) Egypt Maternal and Child Health Survey. 